\title{
Soil-plant-animal transfer models to improve soil protection guidelines: A case study from Portugal
}

\author{
S.M. Rodrigues ${ }^{\text {a,* }}$, M.E. Pereira ${ }^{\text {a }}$, A.C. Duarte ${ }^{\text {a }}$, P.F.A.M. Römkens ${ }^{\text {b }}$ \\ a Centre for Environmental and Marine Studies (CESAM)/Department of Chemistry, Universidade de Aveiro, 3810-193 Aveiro, Portugal \\ ${ }^{\mathrm{b}}$ Alterra - Wageningen University and Research Center, PO Box 47, Wageningen, 6700 AA, The Netherlands
}

\section{A R T I C L E I N F O}

Article history:

Received 17 May 2011

Accepted 13 September 2011

Available online 29 October 2011

\section{Keywords:}

Potentially toxic elements

Plant uptake

Food chain

Human exposure

Soil threshold concentrations

\begin{abstract}
A B S T R A C T
Food chain models are essential tools to assess risks of soil contamination in view of product quality including fodder crops and animal products. Here we link soil to plant transfer (SPT) models for potentially toxic elements (PTEs) including As, $\mathrm{Ba}, \mathrm{Cd}, \mathrm{Co}, \mathrm{Cu}, \mathrm{Hg}, \mathrm{Ni}, \mathrm{Pb}, \mathrm{Sb}, \mathrm{U}$ and $\mathrm{Zn}$ with models describing accumulation in animal organs. Current EU standards for food products and acceptable daily intake levels (ADI) for humans were used as critical limits. The combined model is used to assess the impact of soil contamination on animal health, product quality and human health using data from 100 arable fields. Results indicate that 42 existing arable fields near industrial and mining sites are unsuitable for animal grazing in view of food safety due to elevated intake of $\mathrm{Cd}, \mathrm{Cu}, \mathrm{Hg}$ and $\mathrm{Pb}$ by cows and sheep. At 10 sites daily intake levels of As by cows exceeded threshold concentrations regarding the quality of animal products.

The food chain model also was used inversely to derive soil threshold concentrations in view of EU fodder standards. Calculated threshold levels in soil for As, $\mathrm{Cd}, \mathrm{Cu}, \mathrm{Pb}, \mathrm{Hg}$ and $\mathrm{Zn}$ appear to be in line with those proposed or used in other EU countries. As such the approach applied here can form a conceptual basis for a more harmonized risk assessment strategy regarding the protection of animal and human health.
\end{abstract}

(c) 2011 Elsevier Ltd. All rights reserved.

\section{Introduction}

The EU Thematic Strategy for Soil Protection has clearly identified food and biomass production as one of the key soil functions since the quality and safety of feed and food that are traded freely within the internal market can influence animal and human health throughout Europe (EC, 2006a). Cases of contamination of animal feeding stuffs within the EU have been reported in the past (Beresford et al., 2001; Crews et al., 1992). Hence, it is crucial to develop tools to characterize the pathways relating to soil contamination, plant uptake, dietary transfer of contaminants to animals and finally consumer exposure from dietary intake of plant and animal products. Such tools can be used to determine threshold concentrations of potentially toxic elements (PTEs) in soils in order to deliver safe and high-quality products (de Vries et al., 2007; Franz et al., 2008). To do so, models that use levels of PTEs in soil to predict PTE levels in feed and food crops are needed.

Recent studies reported that the use of a constant bioconcentration factor (BCF) is not appropriate to describe the transfer of PTEs from soils to plants in a wide range of soils (de Vries et al., 2007; Römkens et al., 2009a, 2009b). Mechanistic models however, capable of predicting plant levels for an array of PTEs have not yet been developed, let alone validated under field conditions (Swartjes, 2011). Therefore,

\footnotetext{
* Corresponding author at: Departamento de Química, Universidade de Aveiro, 3810-193 Aveiro, Portugal. Tel.: + 351 234370721; fax: + 351234370084.

E-mail address: smorais@ua.pt (S.M. Rodrigues).
}

empirical models have been proposed as a first approximation to describe soil to plant transfer (SPT). To account for differences in the availability of PTEs in various soil types, important soil properties including $\mathrm{pH}$ and CEC have been included in such models (Efroymson et al., 2001; Krauss et al., 2002; Römkens et al., 2009b). The majority of these studies however considered a limited number of PTEs usually including cadmium $(\mathrm{Cd})$ and lead $(\mathrm{Pb})$ whereas the applicability of the model approach for elements like arsenic (As), nickel (Ni), chromium $(\mathrm{Cr})$, uranium $(\mathrm{U})$, antimony $(\mathrm{Sb})$ has not been tested yet.

To overcome this limitation and to assess the general validity of the SPT approach concentrations of eighteen metals and metalloids in soil ( $\mathrm{Hg}, \mathrm{As}, \mathrm{Cu}, \mathrm{Pb}, \mathrm{Zn}, \mathrm{Cd}, \mathrm{Ni}, \mathrm{Cr}, \mathrm{Co}, \mathrm{Ba}, \mathrm{U}, \mathrm{Fe}, \mathrm{Mn}, \mathrm{Al}, \mathrm{Sb}, \mathrm{Se}, \mathrm{B}$ and Mo) and field-grown feed and food crops were used to derive SPT relationships. Using the SPT models, the exposure of both animals and human to soil contaminants was quantified for some food chains. Finally, SPT transfer models were used to derive soil threshold concentrations for various PTEs in view of existing EU food and fodder quality criteria aiming at the protection of animal and human health (de Vries et al., 2007; Römkens et al., 2009b).

\section{Materials and methods}

\subsection{Study areas and sample collection}

Soil and crop samples from arable fields and pastures were collected in northern, central and south-western regions of Portugal. These 
areas included non-contaminated arable fields from a rural area as well as fields impacted by industry (Chemical Complex of Estarreja) and mining activities (Aljustrel, Caveira and Lousal mines). Such sampling areas were selected in order to obtain samples with a wide range of contamination levels for the various elements. For this, the geogenic variability of PTEs in Portuguese soils (Inacio et al., 2008) as well as previous studies in contaminated sites in Portugal (Rodrigues et al., 2009) were taken into account. More information on the location of sampling sites as well as the degree of contamination is published elsewhere (Rodrigues et al., 2010a).

In total, 105 soil samples (0-15 cm depth) and 105 plant pairs of samples were analyzed. The database contains 73 samples of ryegrass (Lolium perenne), 9 samples of Italian ryegrass (Lolium multiflorum), and 23 samples of collard greens (Brassica oleracea). Mature plants were sampled at time of harvest together with soils. Soil samples were taken in the immediate vicinity of the roots of the crop samples. For grass approximately $100 \mathrm{~g}$ of fresh plant material was collected from both roots and shoots, and transferred into plastic bags. In the case of collard green, one entire plant (root, stem and several leaves) was sampled at each point.

\subsection{Pre-treatment and analysis of soil and plant samples}

Soil samples were air dried until constant weight and sieved at $<2 \mathrm{~mm}$. The $\mathrm{pH}_{\mathrm{CaCl} 2}$ of the soil samples was determined according to the ISO 10390:1994 procedure. To determine organic carbon (OrgC) concentration, carbonates were removed by treating the soil with hydrochloric acid prior to elementary analysis (ISO 10694:1995). Particle size distribution of soil samples was determined using a Coulter LS230 laser diffraction particle size analyzer. Concentrations of amorphous $\mathrm{Fe}$ and $\mathrm{Al}$ oxides $\left(\mathrm{Fe}_{\mathrm{ox}}\right.$ and $\left.\mathrm{Al}_{\mathrm{ox}}\right)$ were determined after extraction of $2.50 \mathrm{~g}$ of soil with $50 \mathrm{~mL}$ of a $0.1 \mathrm{M}$ oxalic acid solution buffered to $\mathrm{pH}$ 3 by ammonium oxalate (Rodrigues et al., 2010a).

Total $\mathrm{Hg}$ concentrations in soil samples $(<2 \mathrm{~mm})$ were determined by thermal decomposition atomic absorption spectrometry with gold amalgamation (LECO model AMA-254) as described by Rodrigues et al. (2010a). Total pools of the remaining PTEs were determined after destruction by aqua regia (ISO 11466:1995) by inductively coupled plasma mass spectrometry (ICP-MS; ISO 17294-1:2005 and ISO 17294-2:2003). The available pool of PTEs was obtained by extraction using a 1:10 (w:v) $0.01 \mathrm{M} \mathrm{CaCl}_{2}$ (Houba et al., 2000). Further details on soil analysis is published by Rodrigues et al. (2010a, 2010b).

Plant samples were thoroughly cleaned with tap water and a brush to remove traces of dust and adhering soil from the roots and leaves. Samples were subsequently rinsed with distilled water (Válega et al., 2008). After washing, all plant samples were dried at $45^{\circ} \mathrm{C}$ until constant weight for at least 4 days (Válega et al., 2008). The dried samples were ground manually in an agate mill.

Determination of total $\mathrm{Hg}$ concentrations in dried samples from plant shoots was also carried out using a LECO model AMA-254. No sample digestion was involved on this process and the analyses were performed in triplicate and directly on the solid samples (Costley et al., 2000). The recovery of total $\mathrm{Hg}$ in the certified reference material (BCR 060 - Aquatic plant (Lagarosiphon major)) ranged from $82.8 \%$ and $119.9 \%$ (mean: $93.4 \% ; n=22$ ). The concentrations of the remaining metals and metalloids in all plant samples (shoots) were determined by ICP-MS after aqua regia digestion. Vegetation samples were pulverized at $450{ }^{\circ} \mathrm{C}$ and a $0.5 \mathrm{~g}$ split of each material was leached in hot $\left(95^{\circ} \mathrm{C}\right)$ aqua regia $\left(\mathrm{HCl}-\mathrm{HNO}_{3}-\mathrm{H}_{2} \mathrm{O}\right)$ for $60 \mathrm{~min}$. Solutions were aspirated into an ICP-MS and 17 elements were analyzed (detection limit between brackets in $\mathrm{mg} \mathrm{L}^{-1}$ unless stated otherwise): Mo (0.01), Cu (0.01), Pb (0.01), Zn (0.1), Ni (0.1), Co (0.01), Mn (1), Fe (0.001\%), As (0.1), U (0.01), Cd (0.01), Sb (0.02), Cr (0.1), Ba (0.1), B (1), Al (0.01\%), and Se (0.1). Duplicate plant samples were digested and analyzed. Six blanks and a total of 8 samples of two internal reference materials were included in the samples batch for analytical quality control (recovery for the various elements was between $88.9 \%$ and $117.6 \%$ ).

\subsection{Statistical analysis of data and model concept}

SPSS 10.0 for Windows was used for descriptive statistics and for statistical analysis of data. In Fig. 1 the overall outline of the model concept applied here is shown. First, levels in crops are calculated using non-linear SPT relationships based on field data (Section 2.3.1). Together with the levels in soil, calculated levels in plants are subsequently used to calculate the daily intake by animals and accumulation in specific animal organs including kidney and liver being the most sensitive ones in view of animal health and food quality (Section 2.3.2). Finally the quality of arable crops and animal products is combined to calculate human exposure (Section 2.3.3) using current ADI levels across the EU. Inverse use of the model chain finally allows for the calculation of soil standards based on critical quality levels in crops and animal products (Section 2.3.4). In contrast to most standards used in the EU nowadays, this allows one to correct for differences between soil types since the SPT models do account for such differences.

\subsubsection{Derivation of SPT transfer models}

SPT transfer models for PTEs were derived using non-linear equations according to de Vries et al. (2007), Kalis et al. (2007), and Krauss et al. (2002):

$[P T E]_{\text {plant }}=k_{s p} \cdot[P T E]_{\text {soil }}^{n}$

where:

$[\mathrm{PTE}]_{\text {soil }}$ total concentration of the PTE in soil measured in mg kg-1 d.w.;

$k_{s p} \quad$ transfer constant from soil to plant in $\mathrm{mg} \mathrm{kg}^{1-\mathrm{n}}$;

$n \quad$ coefficient describing the non-linear relationship

$k_{s p} \quad$ depends on soil properties (Römkens et al., 2009a, 2009b) as described next:

$\log k_{s p}=\log (a)+(b \ldots f) \cdot \log [$ soil_properties $]$

where:

$\log$ [soil_properties] $\log _{10}$ values of soil properties (except pH). Soil properties tested were: $\mathrm{pH}, \log (\operatorname{Org} \mathrm{C}), \log \left(\mathrm{Al}_{\mathrm{ox}}\right)$ and $\log$ $\left(\mathrm{Fe}_{\mathrm{ox}}\right), \log$ (clay).

Using $\log _{10}$ transformation Eq. (1) can therefore be presented as:

$\log [P T E]_{\text {plant }}=\log (a)+(b \ldots f) \cdot \log [$ soil_properties $]+n \cdot \log [P T E]_{\text {soil }}(3)$

Coefficients of Eq. (3) were determined by multiple linear regression analysis.

We also used regression analysis to derive SPT functions in which the log-concentration of a PTE in plants is a function of its respective log-available concentration (given by $0.01 \mathrm{M} \mathrm{CaCl}_{2}$ extraction) in soils (Römkens et al., 2009a). This solution model is given by:

$\log [P T E]_{\text {plant }}=\log \left(a^{\prime}\right)+b^{\prime} \cdot \log [P T E]_{\text {soil(available })}$

2.3.2. Calculation of daily intake (DI), animal organs' concentrations and acceptable daily intake (ADI) of PTEs for animals

The intake of PTEs by animals relates both to feed consumption and soil ingestion (Smith et al., 2009). According to Smith et al. (2009), the DI of PTEs by animals can be calculated by:

$D I_{\text {animal }}=[P T E]_{\text {feed }} \times I_{\text {feed }}+[P T E]_{\text {soil }} \times I_{\text {soil }}$ 


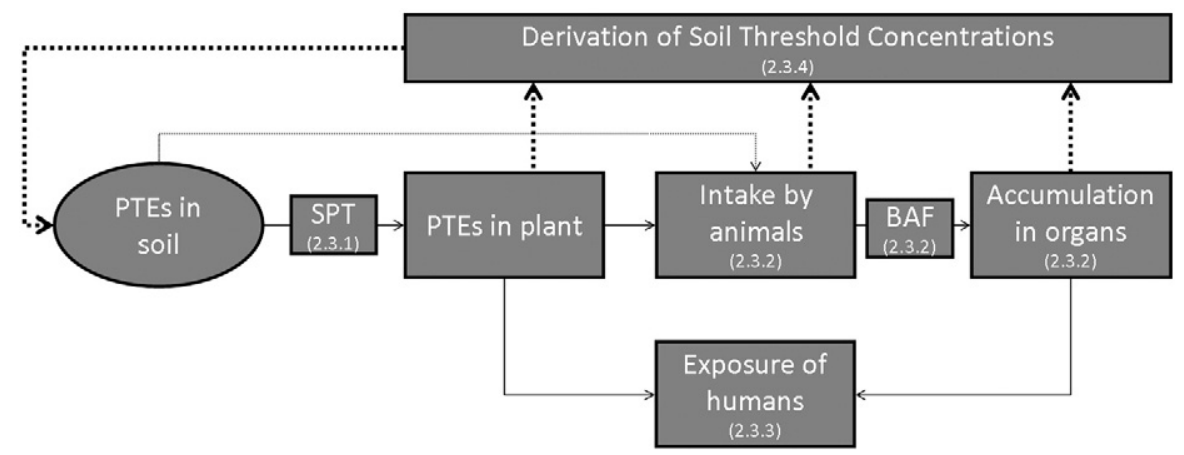

Fig. 1. Overview of model structure described in Section 2.3.1 through 2.3.4.

where:

$\mathrm{DI}_{\text {animal }}$ daily intake of a PTE for grazing animals (cow and sheep) in $\mathrm{mg} \mathrm{d}^{-1}$

$[\mathrm{PTE}]_{\text {feed }},[\mathrm{PTE}]_{\text {soil }}$ concentration of the PTE in feed and soil, respectively, in $\mathrm{mg} \mathrm{kg}^{-1}$ d.w.

$\mathrm{I}_{\text {feed }}, \mathrm{I}_{\text {soil }}$ daily intake of feed and soil, respectively, by grazing animals (cow and sheep) in $\mathrm{kg} \mathrm{d}^{-1}$ d.w. (Table 1)

Calculation of $\mathrm{DI}_{\text {animal }}$ in this study was based on the following assumptions:

- Measured concentrations of PTEs in feed crops were used;

- The calculations were performed on a field-by-field basis assuming that animals graze at the field all the time and always at the same sites.

The concentration of PTEs in animal organs was given by (de Vries et al., 2007):

$$
\begin{aligned}
{[P T E]_{\text {animal_organ }}=} & \left([P T E]_{\text {feed }} \times \frac{I_{\text {feed }}}{I_{\text {feed }}+I_{\text {soil }}}+[P T E]_{\text {soil }} \times \frac{I_{\text {soil }}}{I_{\text {feed }}+I_{\text {soil }}}\right) \\
& \times B A F_{\text {feed-animal }}
\end{aligned}
$$

where:

[PTE $]_{\text {animal_organ }}$ concentration of the PTE in an animal organ (kidney, liver or muscle), in $\mathrm{mg} \mathrm{kg}^{-1}$ f.w.

Table 1

\begin{tabular}{|c|c|c|c|c|}
\hline & & Cow & Sheep & Source \\
\hline$I_{\text {feed }}$ & & $16.9 \mathrm{~kg} \mathrm{~d}^{-1}$ d.w. & $2.5 \mathrm{~kg} \mathrm{~d}^{-1}$ d.w. & $\begin{array}{l}\text { de Vries et al. } \\
\text { (2007) }\end{array}$ \\
\hline \multirow[t]{2}{*}{$\mathrm{I}_{\text {soil }}$} & & $0.41 \mathrm{~kg} \mathrm{~d}^{-1}$ d.w. & $0.10 \mathrm{~kg} \mathrm{~d}^{-1}$ d.w. & $\begin{array}{l}\text { de Vries et al. } \\
\text { (2007) }\end{array}$ \\
\hline & & Humans & & \\
\hline I soil_humans & & $50 \mathrm{mg} \mathrm{d}^{-1}$ d.w. & & $\begin{array}{l}\text { Brand et al. } \\
\text { (2007) }\end{array}$ \\
\hline I leaf_vegetables & & $156.4^{\mathrm{a}} \mathrm{g} \mathrm{d}^{-1}$ f.w. & & INE (2006) \\
\hline \multirow[t]{3}{*}{ I animal_organ } & $\begin{array}{l}\text { cow meat } \\
\text { (muscle) }\end{array}$ & $37.8 \mathrm{~g} \mathrm{~d}^{-1}$ f.w. & & INE (2006) \\
\hline & $\begin{array}{l}\text { sheep meat } \\
\text { (muscle) }\end{array}$ & $6.8 \mathrm{~g} \mathrm{~d}^{-1}$ f.w. & & INE (2006) \\
\hline & $\begin{array}{l}\text { offal (cow } \\
\text { kidney and } \\
\text { liver) }\end{array}$ & $16.4 \mathrm{~g} \mathrm{~d}^{-1}$ f.w. & & INE (2006) \\
\hline
\end{tabular}

Daily intake (DI) parameters used in animal and human exposure calculation.

${ }^{\mathrm{a}}$ From which $78.2 \mathrm{~g} \mathrm{~d}^{-1}$ f.w. were considered Brassica vegetables, for the purpose of this study.
$\mathrm{BAF}_{\text {feed-animal }}$ bioaccumulation factor which corresponds to the concentration of a PTE in an animal organ divided by the concentration in feed $\left(\left(\mathrm{mg} \mathrm{kg}^{-1}\right.\right.$ in animal organ f.w. $) /\left(\mathrm{mg} \mathrm{kg}^{-1}\right.$ in feed d.w.)) (Table 2).

Eq. (6) is based on the following assumptions:

- A linear relationship between the concentration of PTEs in feed and the respective element concentration in animal organs as represented by $\mathrm{BAF}_{\text {feed-animal. }}$.

- The transfer coefficient of PTEs from soil to animal organ is equal to the $\mathrm{BAF}_{\text {feed-animal }}$;

- The PTE intake by air and water is negligible compared to that of soil and feed (de Vries et al., 2007).

A combination of Eqs. (5) and (6) was used to calculate the acceptable daily intake (ADI) for animals in view of food safety and animal health criteria for animal organs:

$A D I_{\text {animals }}=\frac{[P T E]_{\text {limit_animal_organ }} \times\left(I_{\text {feed }}+I_{\text {soil }}\right)}{B A F_{\text {feed-animal }}}$

where:

$\mathrm{ADI}_{\text {animals }}$ acceptable daily intake of each PTE for animals, in $\mathrm{mg} \mathrm{d}^{-1}$ [PTE $]_{\text {limit_animal_organ }}$ limit concentration of the PTE in an animal organ (kidney, liver or muscle) in $\mathrm{mg} \mathrm{kg}^{-1} \mathrm{f.w}$.

The ADI reflects the maximum daily intake of a given PTE so that the concentration of that element in animal organs (kidney, liver or muscle) does not surpass the organ limit concentrations given by food safety and animal health criteria given in Table 2 .

\subsubsection{Calculation of DI of PTEs for humans due to soil ingestion and} dietary intakes of vegetables and animal products

Human intake of PTEs in this study consists of intake by $(i)$ food crops (leaf vegetables); (ii) soil ingestion; and (iii) animal organs including kidney, liver and muscle/meat. These three pathways are shown in Fig. 2(i) as a, b and c, respectively. Obviously other sources of contaminants need to be considered in a full exposure assessment but in this study we focused on the contribution of arable products to the intake by humans.

The DI of PTEs for humans was calculated for four toxic elements (As, $\mathrm{Cd}, \mathrm{Hg}$ and $\mathrm{Pb}$ ) since values for tolerable intakes were available from literature for these elements (EC, 2004). The human DI was calculated according to the following equation:

$$
\begin{aligned}
D I_{\text {humans }}= & {[P T E]_{\text {soil }} \times I_{\text {soil_humans }}+[P T E]_{\text {leaf_vegetables }} \times I_{\text {leaf_vegetables }} } \\
& +[P T E]_{\text {animal_organ }} \times I_{\text {animal_organ }}
\end{aligned}
$$


Table 2

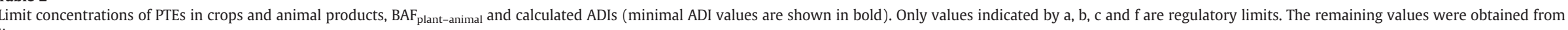
literature.

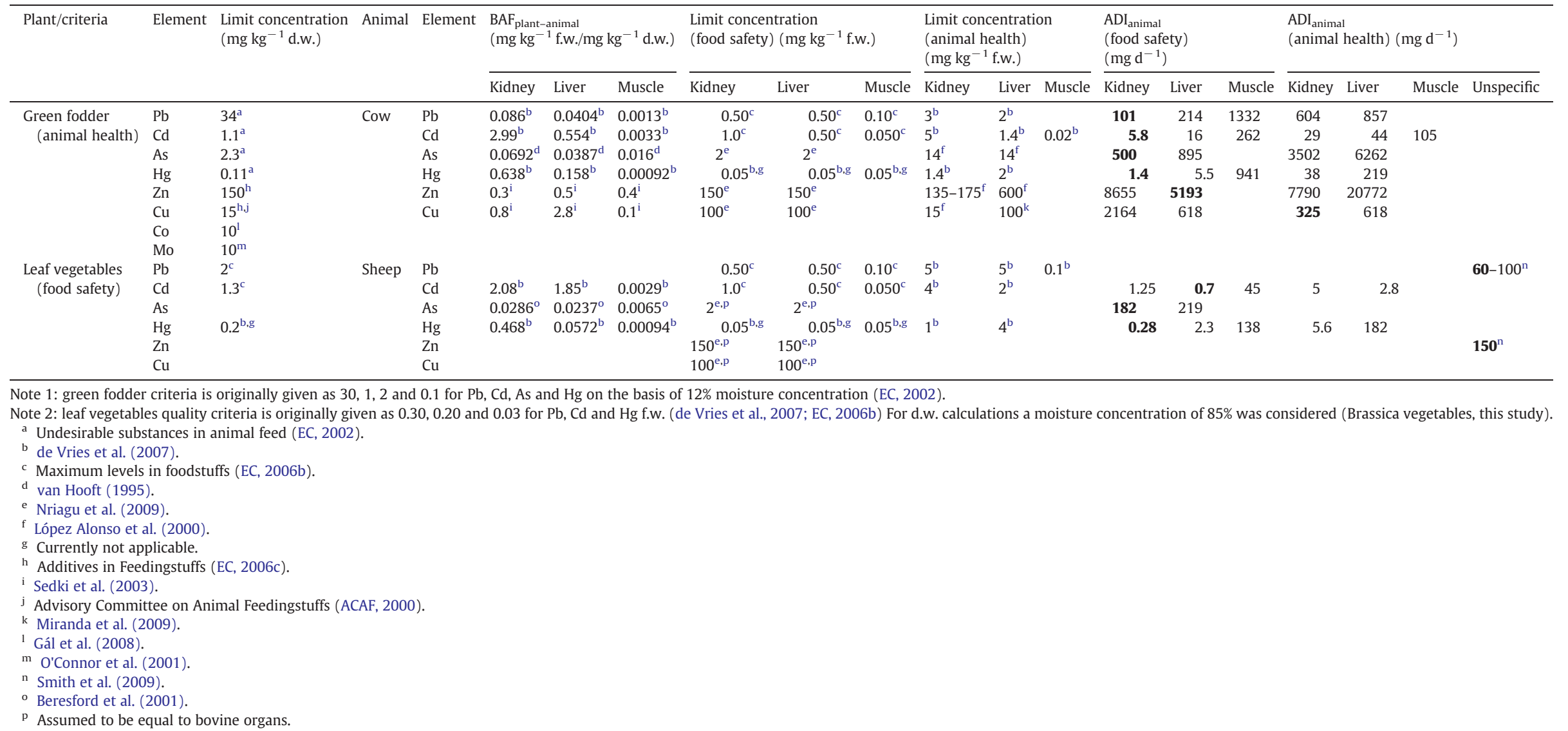

Assumed to be equal to bovine organs. 

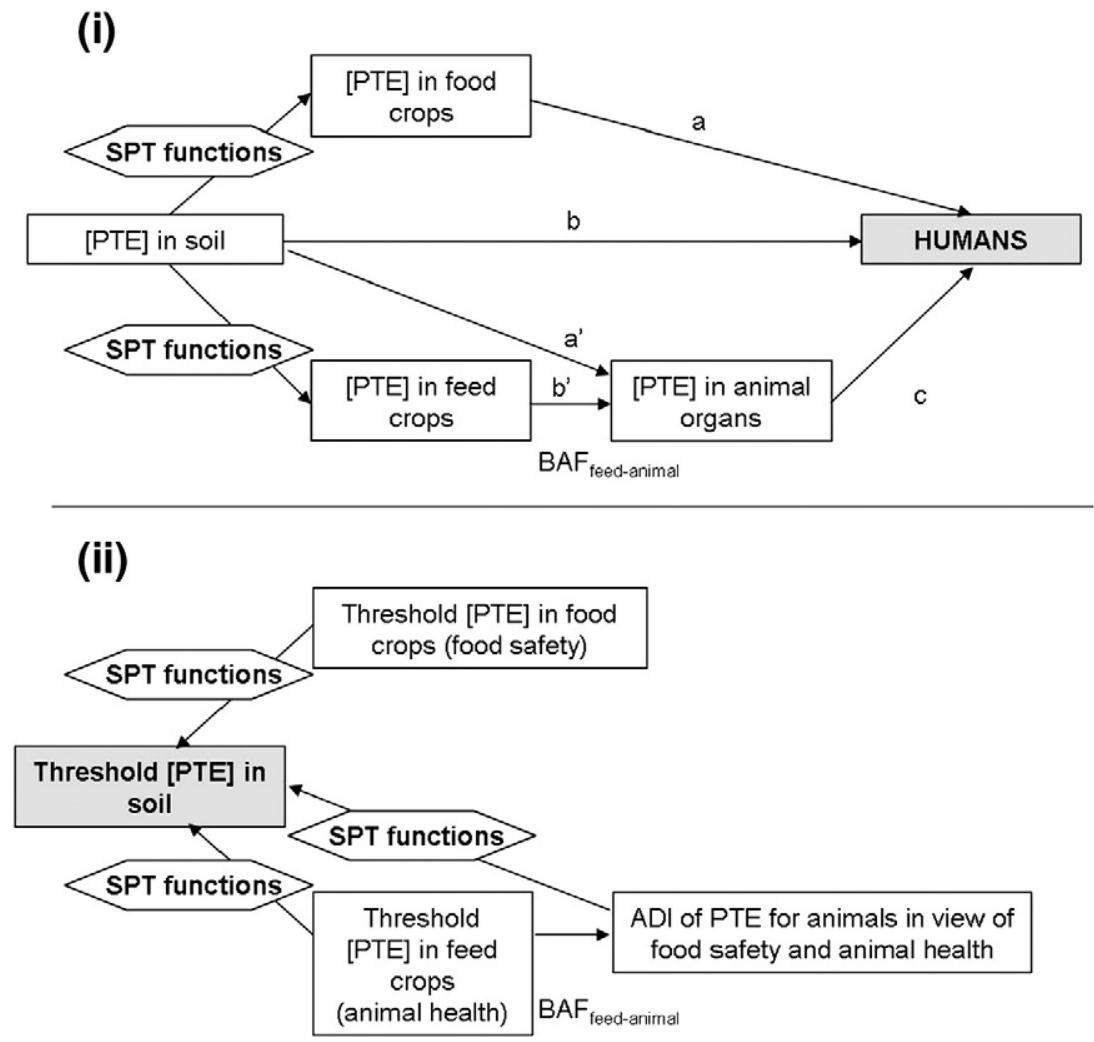

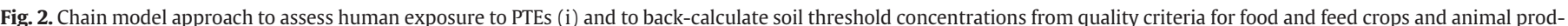

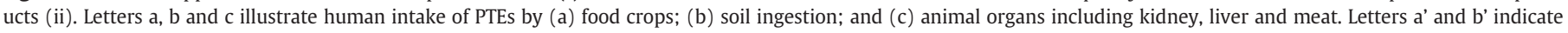
animal intake of PTEs by soil ingestion and feed crops, respectively.

where:

$\mathrm{DI}_{\text {humans }}$ daily intake of a PTE for humans in $\mathrm{mg} \mathrm{d}^{-1}$

$[P T E]_{\text {leaf_vegetables }}$ concentration of a PTE in leaf vegetables, in $\mathrm{mg} \mathrm{kg}{ }^{-1}$ f.w.

$\mathrm{I}_{\text {soil_humans, }} \mathrm{I}_{\text {leaf_vegetables }}$ and $\mathrm{I}_{\text {animal_organ }}$ Human daily intake of soil, leaf vegetables and animal organs (kidney, liver and muscle/ meat), respectively, by humans in $\mathrm{kg} \mathrm{d}^{-1}$ f.w. (Table 1 )
Calculation of $\mathrm{DI}_{\text {humans }}$ was based on the following assumptions:

- PTE concentration in leaf vegetables was given by measured concentrations in B. oleracea samples;

- PTE concentration in animal organs was given by Eq. (6);

- The calculations were performed on a field-by-field basis assuming that all vegetable and animal products originate from a single field with corresponding soil characteristics and PTE levels.

Table 3

Measured concentrations of PTEs in soils and plants (shoots).

\begin{tabular}{|c|c|c|c|c|c|c|c|c|c|}
\hline \multirow[t]{3}{*}{ Element (unit) } & \multicolumn{3}{|l|}{ Soil } & \multicolumn{4}{|c|}{ Feed crop } & \multirow{2}{*}{\multicolumn{2}{|c|}{$\frac{\text { Food crop }}{\text { Brassica oleracea }}$}} \\
\hline & \multirow[b]{2}{*}{$n$} & \multirow{2}{*}{$\frac{\text { Total pool }}{\text { Range }}$} & \multirow{2}{*}{$\frac{\text { Available pool }}{\text { Range }}$} & \multicolumn{2}{|c|}{ Lolium perenne } & \multicolumn{2}{|c|}{ Lolium multiflorum } & & \\
\hline & & & & $n$ & Range & $n$ & Range & $n$ & Range \\
\hline $\mathrm{Hg}\left(\mu \mathrm{g} \mathrm{kg}{ }^{-1}\right.$ d.w. $)$ & 136 & 13-98298 & $0.10-234$ & 71 & $9.8-5400$ & 9 & 8.9-980 & 24 & 10-180 \\
\hline $\mathrm{Cd}\left(\mathrm{mg} \mathrm{kg}^{-1}\right.$ d.w.) & 117 & $0.10-3.7$ & $0.001-0.44$ & 73 & $0.010-5.0$ & 9 & $0.010-0.27$ & 23 & $0.040-0.38$ \\
\hline $\mathrm{Zn}\left(\mathrm{mg} \mathrm{kg}^{-1}\right.$ d.w.) & 134 & 17-1194 & $0.032-46$ & 73 & 14-395 & 9 & $12-134$ & 23 & 19-138 \\
\hline $\mathrm{Cu}\left(\mathrm{mg} \mathrm{kg}^{-1}\right.$ d.w.) & 134 & $7.4-7635$ & $0.072-173$ & 73 & $3.2-56$ & 9 & $3.5-20$ & 23 & 2.1-8.9 \\
\hline $\mathrm{Pb}\left(\mathrm{mg} \mathrm{kg}^{-1}\right.$ d.w.) & 134 & $10-11546$ & $0.016-208$ & 73 & $0.080-554$ & 9 & $0.57-68$ & 23 & $0.050-1.9$ \\
\hline $\mathrm{Ni}\left(\mathrm{mg} \mathrm{kg}^{-1}\right.$ d.w.) & 134 & $4.5-45$ & $0.029-2.5$ & 73 & $0.50-48$ & 9 & $2.7-7.3$ & 23 & $0.30-3.8$ \\
\hline Co (mg kg ${ }^{-1}$ d.w.) & 134 & $0.50-49$ & $0.0055-2.4$ & 73 & $0.050-3.4$ & 9 & $0.12-1.0$ & 23 & $0.040-0.65$ \\
\hline $\operatorname{Mn}\left(\mathrm{mg} \mathrm{kg}^{-1}\right.$ d.w.) & 134 & $58-2439$ & $0.55-118$ & 73 & 11-935 & 9 & 83-214 & 23 & 10-176 \\
\hline Fe (\% d.w.) & 132 & $0.32-10$ & $0.00001-0.093$ & 73 & $0.010-0.31$ & 9 & $0.022-0.11$ & 23 & $0.015-0.059$ \\
\hline As ( $m g \mathrm{~kg}^{-1}$ d.w.) & 134 & $6.3-2189$ & 0.016-103 & 73 & $0.10-56$ & 9 & $0.10-13$ & 23 & $0.20-1.1$ \\
\hline $\mathrm{U}\left(\mathrm{mg} \mathrm{kg}^{-1}\right.$ d.w.) & 131 & $0.20-13$ & $0.0010-0.33$ & 73 & $0.010-0.20$ & 9 & $<0.01-0.02$ & 23 & $<0.01-0.020$ \\
\hline $\mathrm{Cr}\left(\mathrm{mg} \mathrm{kg}^{-1}\right.$ d.w. $)$ & 130 & $2.0-70$ & $0.0042-1.9$ & 73 & $0.80-110$ & 9 & $3.3-8.9$ & 23 & $0.80-4.4$ \\
\hline Ba (mg kg ${ }^{-1}$ d.w.) & 134 & 16-599 & $0.61-55$ & 73 & $1.4-80$ & 9 & $8.2-35$ & 23 & $9.2-70$ \\
\hline $\mathrm{Al}$ (\% d.w.) & 134 & $0.42-3.4$ & $0.0001-0.072$ & 73 & $0.01-0.13$ & 9 & $<0.01-0.03$ & 23 & $<0.01-0.14$ \\
\hline $\mathrm{Sb}\left(\mathrm{mg} \mathrm{kg}^{-1}\right.$ d.w.) & 112 & $0.10-220$ & $0.004-1.1$ & 73 & $<0.02-15$ & 9 & $0.020-2.6$ & 23 & $0.020-0.12$ \\
\hline Se (mg kg-1 d.w.) & 54 & $0.50-19$ & $0.010-0.27$ & 73 & $0.1-0.28$ & 9 & $0.1-0.4$ & 23 & $0.1-1.3$ \\
\hline Mo (mg kg-1 d.w.) & 23 & $0.50-1.6$ & $0.0011-0.016$ & 73 & $0.10-5.0$ & 9 & $0.080-0.58$ & 23 & $0.11-7.3$ \\
\hline B ( $\mathrm{mg} \mathrm{kg}^{-1}$ d.w.) & 23 & $3.2-16$ & $0.11-2.1$ & 73 & $1.0-20$ & 9 & $<1-3.0$ & 23 & $12-58$ \\
\hline
\end{tabular}


Since limits for human tolerable intakes for inorganic contaminants available from literature are given on a weekly basis and per kilogram of body weight (Provisional Tolerable Weekly Intake, PTWI) we have multiplied calculated DIs by seven to obtain the respective weekly intakes and assumed a body weight of $70 \mathrm{~kg}$ (adult).

2.3.4. Calculation of soil threshold concentrations of PTEs in soils using soil to plant transfer (SPT) functions

Soil threshold concentrations can be back-calculated from green fodder limits in Table 2, using Eq. (3) (Brus et al., 2005; de Vries et al., 2007), as following:

$\log [P T E]_{\text {soil_threshold }}=\frac{\log [P T E]_{\text {limit_plant }}-\log (a)-(b \ldots i) \cdot \log [\text { soil_properties }]}{n}$

As illustrated in Fig. 2(ii), limit concentrations in food crops (limit values in leaf vegetables regarding food safety, Table 1) as well as limit concentration in feed crops (limit values in green fodder regarding animal health, Table 1) can be used to calculate soil threshold concentrations.

Similarly, threshold concentrations of PTEs in soils can be back-calculated from ADIs for grazing animals (Fig. 2(ii)). These soil threshold concentrations are the maximum values at which the concentrations of contaminants in animal organs (kidney, liver and muscle/meat) will not surpass food safety and/or animal health criteria (de Vries et al., 2007) and were calculated iteratively from a combination of Eq. (1) and Eq. (5) as following:

$A D I_{\text {animals }}=\left(k_{s p} \times[P T E]_{\text {soil_threshold }}^{n}\right) \times I_{\text {feed }}+[P T E]_{\text {soil }} \times I_{\text {soil_threshold }}$

where $k_{s p}$ and $n$ values for each element were given by SPT transfer models.

\section{Results and discussion}

\subsection{Characterization of soil and plant samples}

Soils included in this study are representative for the majority of Portuguese soils and tend to be acidic to neutral ( $\mathrm{pH}$ 3.1-7.0; median: 5.1), with low to medium OrgC concentrations (1.1-5.3\%; median: $2.5 \%$ ) and with clay percentages varying between 7 and 21\% (median: 9.0\%). The concentrations of amorphous $\mathrm{Al}$ and $\mathrm{Fe}$ oxides in these samples were highly variable and range from 7.9 to $240 \mathrm{mmol} \mathrm{kg}^{-1}$ for $\mathrm{Al}$ and from 11 to $183 \mathrm{mmol} \mathrm{kg}^{-1}$ for Fe.

A summary of the total and available concentrations of PTEs in soils is listed in Table 3. Elevated total levels of $\mathrm{As}, \mathrm{Hg}, \mathrm{Zn}, \mathrm{Cu}, \mathrm{Pb}, \mathrm{Cd}$ and Ba were observed in soils from the industrial and mining sites, when compared to Portuguese non-contaminated soils (Inacio et al., 2008). Maximum total $\mathrm{Hg}$ levels reached $98 \mathrm{mg} \mathrm{kg}^{-1}$ while maximum As, $\mathrm{Cu}$ and $\mathrm{Pb}$ concentrations were as high as 2189,7635 and $11546 \mathrm{mg} \mathrm{kg}^{-1}$, respectively (Table 3 ). Such levels are an indication of severe soil contamination and hence may lead to a considerable exposure to animals and/or human beings through intake of soil and food. The concentrations of PTEs in plant tissues from this dataset are also shown in Table 3. Maximum concentrations of $\mathrm{Hg}\left(5.4 \mathrm{mg} \mathrm{kg}^{-1}\right), \mathrm{Cd}$ (5.0 mg kg-1), Pb (554 $\left.\mathrm{mg} \mathrm{kg}^{-1}\right)$, As (56 mg kg-1), Cu (56 mg kg-1), Ni $\left(48 \mathrm{mg} \mathrm{kg}^{-1}\right)$

Table 4

Derived SPT functions for the different crops analyzed.

\begin{tabular}{|c|c|c|c|c|c|c|c|c|c|c|}
\hline & \multirow[t]{3}{*}{ PTEs } & \multicolumn{9}{|c|}{ Linear regression coefficients (Eq. (7)) } \\
\hline & & \multicolumn{6}{|c|}{$\left[\mathrm{PTE}_{\text {plant }}\right]=f\left(\mathrm{PTE}_{\text {soil total pool }}+\right.$ soil properties $)$} & \multicolumn{3}{|c|}{$\left[\mathrm{PTE}_{\text {plant }}\right]=f\left(\mathrm{PTE}_{\text {soil available pool }}\right)$} \\
\hline & & $\begin{array}{l}\log (a) \\
\text { (interc.) }\end{array}$ & $\begin{array}{l}b \\
(\mathrm{pH})\end{array}$ & $\begin{array}{l}c \\
(\log \% \text { OrgC })\end{array}$ & $\begin{array}{l}d \\
\left(\log \mathrm{Al}_{\mathrm{ox}}\right)\end{array}$ & $\begin{array}{l}n \\
\left(\log \left[\mathrm{PTE}_{\text {total }}\right]\right)\end{array}$ & $r^{2}$ & $\begin{array}{l}\log (a) \\
\text { (interc.) }\end{array}$ & $\begin{array}{l}n \\
\left(\log \left[\mathrm{PTE}_{\text {available }}\right]\right)\end{array}$ & $r^{2}$ \\
\hline \multirow[t]{11}{*}{ Lolium perenne $(\mathrm{n}=73)$} & $\mathrm{Hg}$ & 0.83 & & & -0.29 & 0.52 & 0.64 & 1.7 & 0.56 & 0.40 \\
\hline & $\mathrm{Cd}$ & 0.76 & -0.15 & -0.79 & & 0.82 & 0.52 & 0.44 & 0.70 & 0.53 \\
\hline & $\mathrm{Zn}$ & 1.5 & -0.11 & -0.51 & & 0.53 & 0.60 & 1.7 & 0.36 & 0.68 \\
\hline & $\mathrm{Cu}$ & 1.1 & -0.10 & -0.41 & & 0.34 & 0.50 & 1.1 & 0.28 & 0.38 \\
\hline & $\mathrm{Pb}$ & & & & -0.56 & 0.95 & 0.72 & 0.31 & 0.66 & 0.39 \\
\hline & As & -0.55 & & & -0.29 & 0.71 & 0.56 & 0.46 & 0.36 & 0.24 \\
\hline & $\mathrm{Ni}$ & & & & & 0.49 & $0.10^{*}$ & 0.70 & 0.28 & $0.06^{*}$ \\
\hline & Co & & -0.16 & -0.66 & & 0.94 & 0.51 & & 0.51 & 0.33 \\
\hline & $\mathrm{Ba}$ & n.s. & & & & & & 0.90 & 0.37 & 0.17 \\
\hline & $\mathrm{U}$ & -1.5 & & & & 0.39 & $0.16^{*}$ & n.s. & & \\
\hline & $\mathrm{Sb}$ & & -0.22 & & & 0.69 & 0.60 & & 0.69 & $0.24^{*}$ \\
\hline \multirow[t]{11}{*}{ Lolium multiflorum $(\mathrm{n}=9)$} & $\mathrm{Hg}$ & & & & & 0.63 & 0.95 & 1.8 & 0.76 & 0.74 \\
\hline & $\mathrm{Cd}$ & & -0.54 & & & 1.1 & 0.73 & 0.85 & 1.1 & 0.92 \\
\hline & $\mathrm{Zn}$ & & & & & 0.88 & 0.75 & 1.4 & 0.39 & 0.53 \\
\hline & $\mathrm{Cu}$ & -0.34 & & & & 0.55 & 0.83 & 0.85 & 0.28 & 0.49 \\
\hline & $\mathrm{Pb}$ & -1.3 & & & & 0.83 & 0.91 & 0.74 & 0.59 & 0.71 \\
\hline & As & -1.7 & & & & 0.98 & 0.86 & 0.64 & 0.71 & 0.74 \\
\hline & $\mathrm{Ni}$ & n.s. & & & & & & n.s. & & \\
\hline & Co & -2.3 & & & & 1.3 & $0.48^{*}$ & n.s. & & \\
\hline & $\mathrm{Ba}$ & & -0.21 & & & 0.85 & 0.63 & 0.76 & 0.58 & 0.66 \\
\hline & $\mathrm{U}$ & n.s. & & & & & & n.s. & & \\
\hline & $\mathrm{Sb}$ & -0.96 & & & & 0.58 & 0.83 & 0.32 & 0.37 & 0.71 \\
\hline \multirow[t]{11}{*}{ Brassica oleracea $(n=23)$} & $\mathrm{Hg}$ & & & & & 0.53 & $0.39 *$ & n.s. & & \\
\hline & $\mathrm{Cd}$ & n.s. & & & & & & n.s. & & \\
\hline & $\mathrm{Zn}$ & n.s. & & & & & & 1.6 & 0.20 & 0.17 \\
\hline & $\mathrm{Cu}$ & n.s. & & & & & & n.s. & & \\
\hline & $\mathrm{Pb}$ & -1.9 & & & & 0.86 & $0.26^{*}$ & n.s. & & \\
\hline & As & n.s. & & & & & & n.s. & & \\
\hline & $\mathrm{Ni}$ & n.s. & & & & & & & 0.32 & $0.20^{*}$ \\
\hline & Co & & -0.23 & & -0.31 & 0.74 & $0.55^{*}$ & -0.34 & 0.40 & $0.37^{*}$ \\
\hline & $\mathrm{Ba}$ & n.s. & & & & & & 1.1 & 0.56 & $0.26^{*}$ \\
\hline & $\mathrm{U}$ & n.s. & & & & & & n.s. & & \\
\hline & $\mathrm{Sb}$ & n.s. & & & & & & & 0.4 & $0.68^{*}$ \\
\hline
\end{tabular}

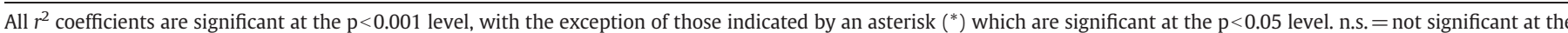
$\mathrm{p}<0.05$ level. 
and $\mathrm{Cr}$ (110 $\mathrm{mg} \mathrm{kg}^{-1}$ ) observed in L. perenne samples were comparable to those obtained for forage samples from highly contaminated areas (Kabata-Pendias, 2001; Miranda et al., 2009; Reis et al., 2009). Concentrations in feed, particularly in L. perenne were generally higher than those in B. oleracea, with the exception of B, Se and Mo that reached levels of $58,1.3$, and $7.3 \mathrm{mg} \mathrm{kg}^{-1}$, respectively in the food crop. The ability of certain Brassica species to extract B from soils was also reported by other authors although the values of $\mathrm{B}$, Se and Mo here observed can be considered tolerable in agronomic crops (KabataPendias, 2001).

Concentration of PTEs in plant shoots was compared with limit levels in leaf vegetables and green fodder according to current EU legislation, given in Table 2. The concentrations of $\mathrm{Cd}, \mathrm{Pb}$ and $\mathrm{Hg}$ in $B$. oleracea samples remained below food safety limits. In contrast, levels of $\mathrm{Hg}, \mathrm{Pb}, \mathrm{As}, \mathrm{Cu}, \mathrm{Cd}$ and $\mathrm{Zn}$ in feed products from industrial and mining sites largely exceeded the EU limits in green fodder which suggests a potential risk in view of animal health or product quality.

\subsection{Derivation of SPT functions}

Results of multiple regression analysis for derivation of SPT as a function of both available soil pools and total pools and soil properties for the PTEs for which significant relationships could be derived are shown in Table 4. Both empirical SPT models using the total element concentrations and soil properties as well as the $\mathrm{CaCl}_{2}$ soil test were able to explain between 50 and $72 \%$ of the variability in levels of $\mathrm{Hg}, \mathrm{Cd}, \mathrm{Zn}, \mathrm{Cu}, \mathrm{Pb}, \mathrm{As}$, $\mathrm{Co}$ and $\mathrm{Sb}$ in L. perenne crops and between 48 and $95 \%$ of the levels of $\mathrm{Hg}, \mathrm{Cd}, \mathrm{Zn}, \mathrm{Cu}, \mathrm{Pb}$ As, $\mathrm{Co}, \mathrm{Ba}$ and $\mathrm{Sb}$ in L. multiflorum. The lowest $r^{2}$ values were observed for B. oleracea $\left(r^{2}: 0.17-0.68\right)$. With the exception of $\mathrm{Co}$ and $\mathrm{Sb}$, the relationships derived for $B$. oleracea did not allow the estimation of PTE plant concentrations from soil values.

3.3. Animal exposure to PTEs in soil and feed

The DIs of PTEs for both cow and sheep are given in Table 5. These values were compared with minimal animal ADI values shown in Table 2.

\subsubsection{Arsenic}

Total DI of As for cows and sheep was up to 1408 and $253 \mathrm{mg} \mathrm{d}^{-1}$, respectively (Table 5). The median contribution of soil ingestion to the total intake was 50 and $62 \%$ for cow and sheep respectively. The cow ADI for As regarding food safety $\left(500 \mathrm{mg} \mathrm{d}^{-1}\right.$ ) was exceeded at 10 sites from a total of 82 studied sites ( 5 at the industrial area and 5 at the mining areas) while the ADI for sheep (182 $\left.\mathrm{mg} \mathrm{d}^{-1}\right)$ was exceeded at 3 sites. The consumption of offal from animal grazing at those sites should therefore be avoided.

\subsubsection{Cadmium}

Values of total Cd DI were in the range of $0.2-85 \mathrm{mg} \mathrm{d}^{-1}$ for cows and $0.03-13 \mathrm{mg} \mathrm{d}^{-1}$ for sheep. The majority of $\mathrm{Cd}$ intake by animals is associated with grass ingestion (median contribution for total intake was 96 and $93 \%$ for cows and sheep, respectively). In all, 32 sites (from the 89 sites studied) were associated with cow DI $>5.8 \mathrm{mg} \mathrm{d}^{-1}$ (ADI for cows in view of offal consumption by humans). The majority (23) of these sites were located at the industrial area. For sheep, 25 industrial and 16 mining sites also showed estimates of DI which surpassed the ADI for food safety. The human consumption of offal from cattle grazing at these areas should be avoided.

\subsubsection{Copper}

Estimates of total $\mathrm{Cu}$ DI for cows varied between 65 and $1133 \mathrm{mg} \mathrm{d}^{-1}$ in the 89 site studies and were above ADI in view of animal health protection at 32 of these sites (22 of these sites were located in mining areas). This intake was primarily associated with grass ingestion (median $\mathrm{Cu}$ intake through grass was $81 \%$ ). Total DI for cows also exceeded food safety ADI $\left(618 \mathrm{mg} \mathrm{d}^{-1}\right)$ in 9 mining sites. No ADI values for sheep were found in literature.

\subsubsection{Lead}

Total DI of Pb was in the range 9.0-10496 and $1.7-1685 \mathrm{mg} \mathrm{d}^{-1}$ for cows and sheep, respectively. The ADI of $101 \mathrm{mg} \mathrm{d}^{-1}$ (for cows, in view of food safety) was surpassed in 31 sampling sites while the ADI for sheep $\left(60 \mathrm{mg} \mathrm{d}^{-1}\right)$ was exceeded in 21 sites (in a total of 89 sites studied). Sites where $\mathrm{Pb}$ ADIs were exceeded were primarily located at the mining areas (all Caveira sites exhibited DI $>$ ADI for both cows and sheep). Fields from Caveira were therefore found not adequate for animal grazing given potential risks for both human and animal health associated with $\mathrm{Pb}$ intake. Similarly to As the median contribution of soil ingestion to the total intake of $\mathrm{Pb}$ was over $50 \%$ (52 and $64 \%$ for cow and sheep, respectively).

\subsubsection{Mercury}

Values of total DI of Hg were in the range $0.18-132 \mathrm{mg} \mathrm{d}^{-1}$ for cows and 0.08 $23 \mathrm{mg} \mathrm{d}^{-1}$ for sheep in a total of 80 sites studied. The Hg intake was for most cases associated with grass (median contribution of grass ingestion to the total intake was 81 and $72 \%$ for cow and sheep, respectively). In all, 27 sites were found unsuitable for both cows and sheep grazing due to exceedance of $\mathrm{Hg}$ ADI in view of food safety ( $1.4 \mathrm{mg} \mathrm{d}^{-1}$ for cows and $0.28 \mathrm{mg} \mathrm{d}^{-1}$ for sheep). These sites were located at the industrial area (13 sites) and at the Caveira mining area (14 sites). The consumption of offal from animals grazing in these areas should therefore be avoided.

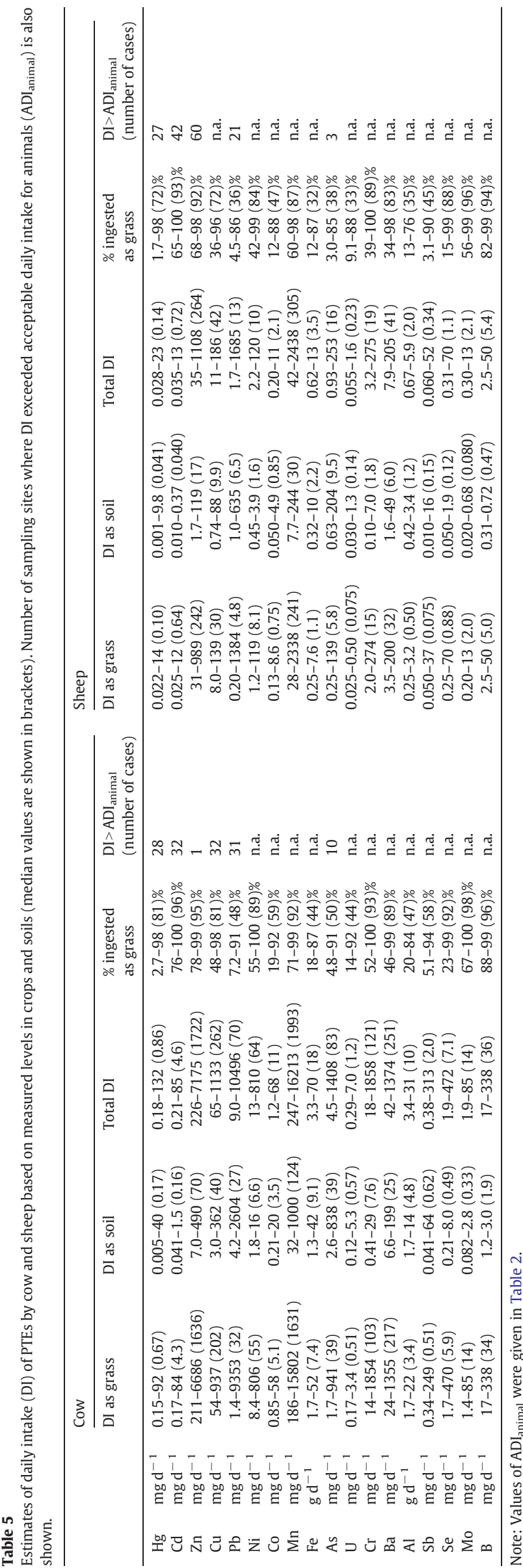


3.3.6. Other PTES

Grass was the main intake pathway of $\mathrm{Zn}, \mathrm{Cr}$, Ba, Se, Mo and B for cows and sheep (median contribution from grass ingestion was over $80 \%$ ) while in the case of $\mathrm{Sb}, \mathrm{Co}$ and $\mathrm{U}$ soil ingestion is associated with most of the intake, particularly for sheep (median intake through soil ingestion is over $50 \%$ ). In the case of $\mathrm{Zn}$ the ADI for cows in view of food safety ( $5193 \mathrm{mg} \mathrm{d}^{-1}$ ) was surpassed in only one site from the industrial area while for sheep a total of 60 sites were associated with DI $>$ ADI $\left(150 \mathrm{mg} \mathrm{d}^{-1}\right)$. These included all industrial sites and the majority of samples from the mining areas. Given the disparity in results for cows and sheep the intake levels at which $\mathrm{Zn}$ may affect animal organs need to be further analyzed. No animal ADI values were obtained for the remaining PTEs.

\subsection{Human exposure to PTEs through diet}

Estimated weekly intake of $\mathrm{As}, \mathrm{Cd}, \mathrm{Hg}$ and $\mathrm{Pb}$ for humans through diet are given in Fig. 3(i).

\subsubsection{Arsenic}

For As, the estimated weekly intake at the various study sites varied between 0.01 and $3.5 \mathrm{mg} \mathrm{w}^{-1}$ ( mean $=0.20 \mathrm{mg} \mathrm{w}^{-1}$; median $=0.06 \mathrm{mg} \mathrm{w}^{-1}$ ) (Fig. 3(i)). A PTWI has been established for As in drinking water in the form of inorganic arsenic but not for foodstuffs (EC, 2004). The median contribution of soil ingestion to As total intake equaled 37\%, followed by consumption of offal (34\%) and meat (25\%). The removal of offal from the food chain has been recommended as an option to reduce human dietary contaminants intake from animal origin (Prankel et al., 2005). The removal of offal from diet would allow an average reduction of $32 \%$ in As weekly intake at our study sites (Fig. 3(ii)).

\subsubsection{Cadmium}

For $\mathrm{Cd}$, the estimated weekly intake at the various sites varied between 0.01 and $1.0 \mathrm{mg} \mathrm{w}^{-1}$ (mean $=0.09 \mathrm{mg} \mathrm{w}^{-1}$; median $=0.05 \mathrm{mg} \mathrm{w}^{-1}$ ) (Fig. 3(i)). A PTWI of
$0.49 \mathrm{mg} \mathrm{w}^{-1}$ for a person weighing $70 \mathrm{~kg}$ has been recommended for $\mathrm{Cd}$ by the WHO (EC, 2004). According to our estimates the PTWI is exceeded in only 3 of the sites (Fig. 3(i)). The major intake of $\mathrm{Cd}$ is from consumption of offal which equals $76 \%$ of the Cd dietary intake (median value). By removing offal from diet, the weekly intake of Cd remains well below the PTWI at all sites (Fig. 3(ii)).

3.4.3. Mercury

For $\mathrm{Hg}$, the estimated weekly intake at the various study sites varied between 0.0004 and $0.4 \mathrm{mg} \mathrm{w}^{-1}$ (mean $=0.02 \mathrm{mg} \mathrm{w}^{-1}$; median $=0.003 \mathrm{mg} \mathrm{w}^{-1}$ ). A PTWI of $0.35 \mathrm{mg} \mathrm{w}^{-1}$ has been recommended for $\mathrm{Hg}$ (EC, 2004) which was exceeded at 2 sites (Fig. 3(i)). The removal of offal from diet allows for an average reduction of $83 \%$ of $\mathrm{Hg}$ dietary intake (Fig. 3(ii)) which again would result in exposure levels well below the PTWI for $\mathrm{Hg}$.

\subsubsection{Lead}

Estimated weekly intake of $\mathrm{Pb}$ varied between 0.01 and $6.5 \mathrm{mg} \mathrm{w}^{-1}$ ( mean $=0.3 \mathrm{mg} \mathrm{w}^{-1}$; median $=0.06 \mathrm{mg} \mathrm{w}^{-1}$ ). The PTWI for $\mathrm{Pb}$ of $1.75 \mathrm{mg} \mathrm{w}^{-1}$ was exceeded at most sites from Caveira area (identified as (d) in Fig. 3(i)). On average, soil ingestion contributes for $40 \%$ of $\mathrm{Pb}$ intake while offal consumption contributes for $52 \%$. After removal of offal from diet there were still 2 Caveira sites at which the PTWI was exceeded due to high $\mathrm{Pb}$ levels in soil (Fig. 3(ii)).

\subsection{The use of soil-plant-animal transfer models to improve soil protection guidelines}

Soil threshold concentrations of $\mathrm{Cd}, \mathrm{Hg}, \mathrm{Pb}, \mathrm{As}, \mathrm{Cu}$ and $\mathrm{Zn}$ (both total and available concentrations) back-calculated from green fodder limits and $\mathrm{ADI}_{\text {animal }}$ values are shown in Table 6. Soil threshold concentrations currently in use at Portugal, UK, the Netherlands and Flanders were also included for comparison. (i)

As

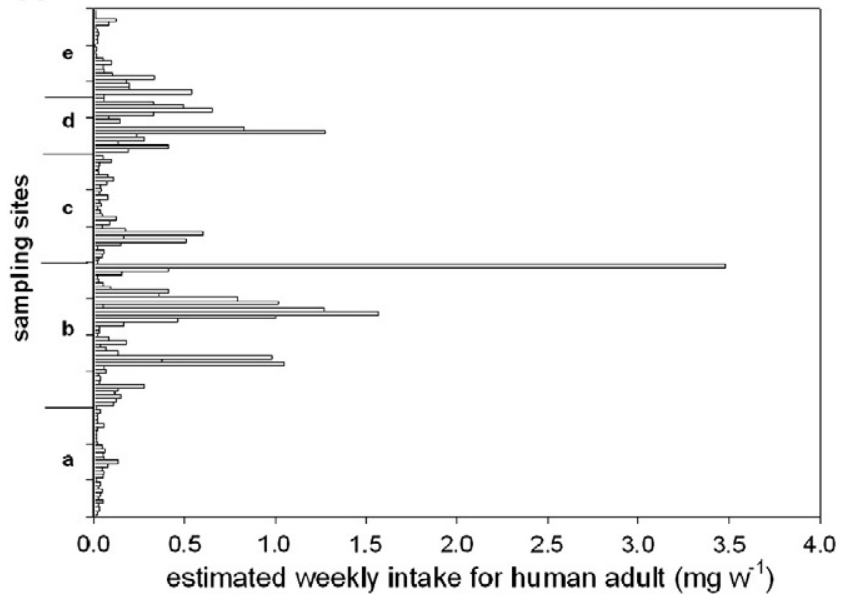

$\mathrm{Hg}$

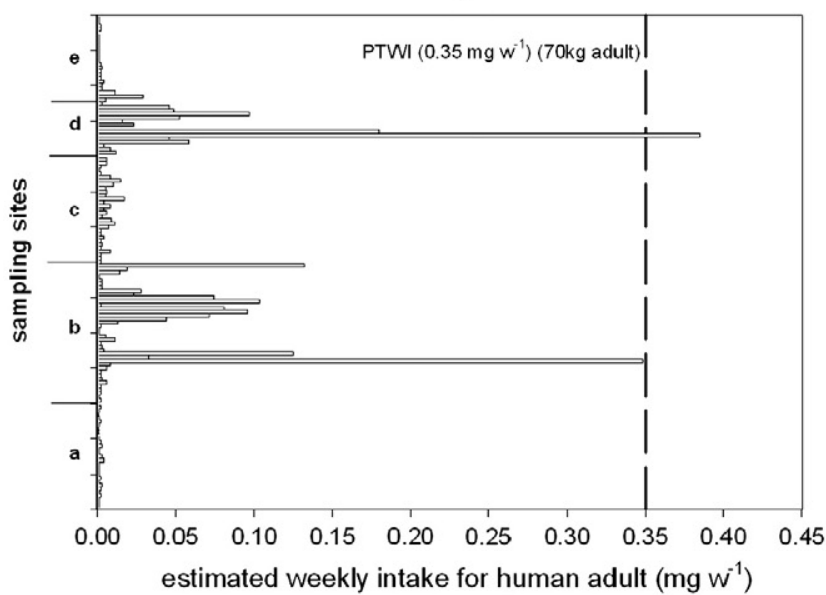

Cd

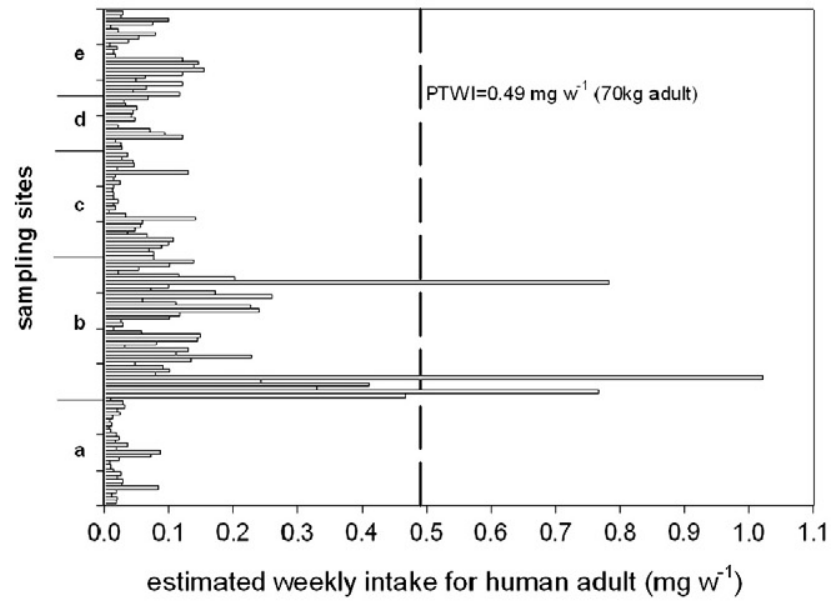

$\mathrm{Pb}$

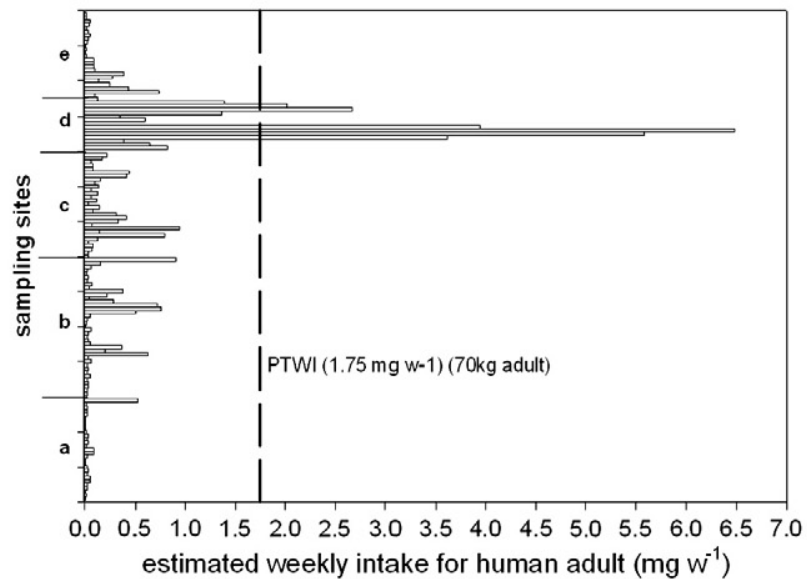

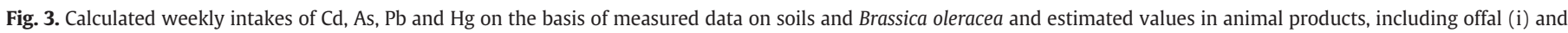
excluding offal (ii) from calculations. Sampling sites include the areas of Esposende (a), Estarreja (b), Lousal (c), Caveira (d) and Aljustrel (e) in Portugal. 
(ii)

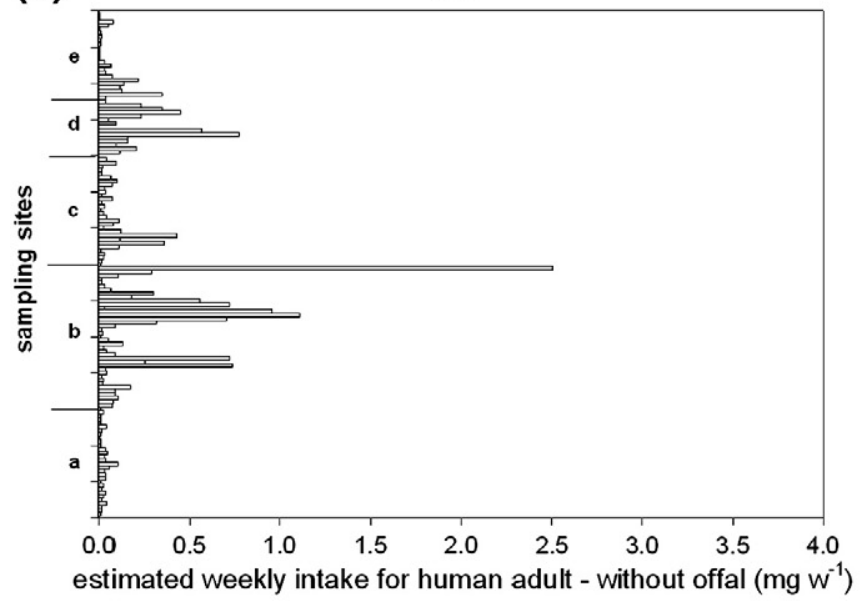

$\mathrm{Hg}$

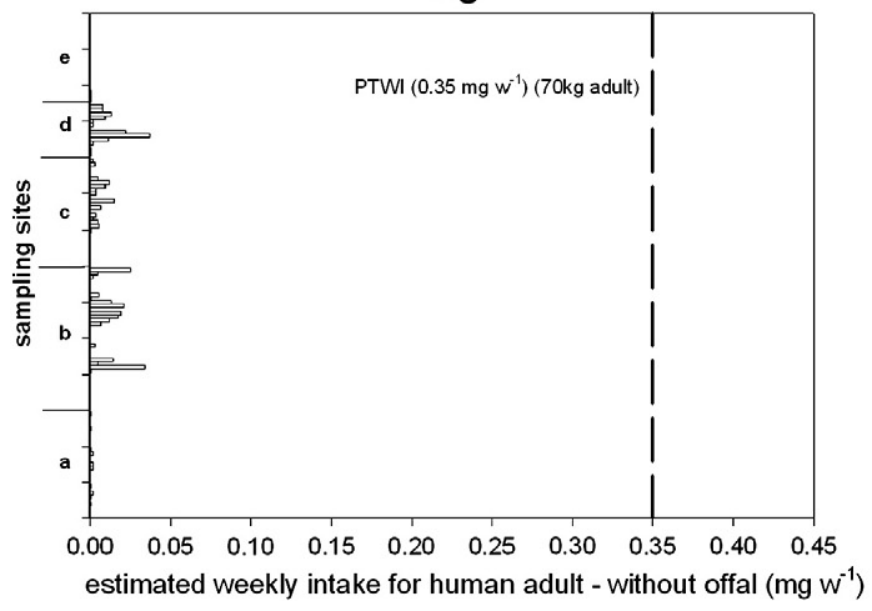

Cd

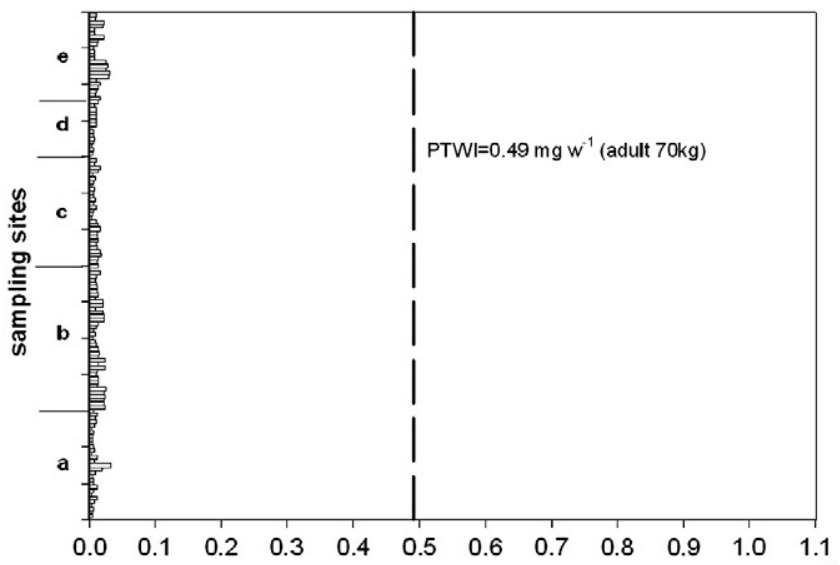

estimated weekly intake for human adult - without offal ( $\left.\mathrm{mg} \mathrm{w}^{-1}\right)$

$\mathrm{Pb}$

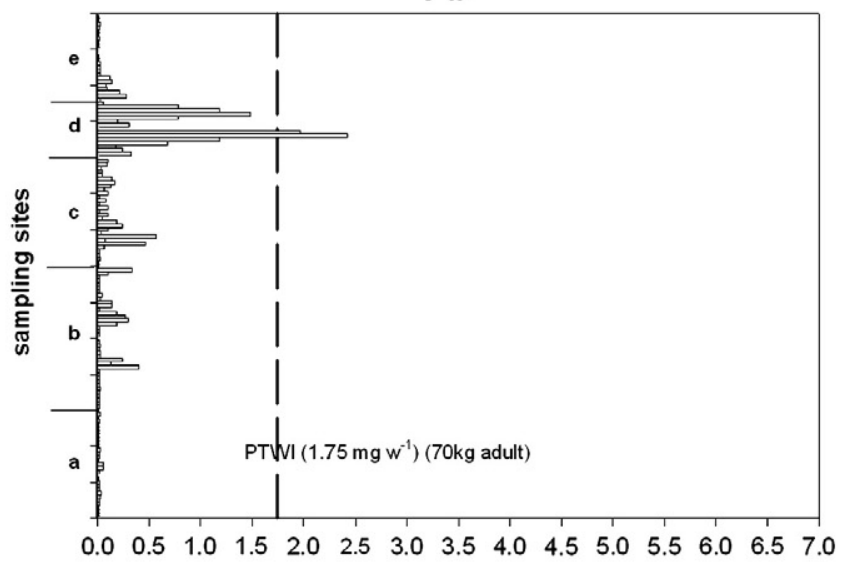

estimated weekly intake for human adult - without offal ( $\left.\mathrm{mg} \mathrm{w}^{-1}\right)$

Fig. 3 (continued).

From Table 6 it is clear that for elements such as $\mathrm{Cd}, \mathrm{Zn}, \mathrm{Cu}$ and $\mathrm{Pb}$ the characteristics of soil significantly affect the soil level at which the contaminant will exceed limit levels in crops and may pose risks in terms of food safety and animal health. For example with a variation in $\mathrm{pH}$ from 4 to 6 , the soil's total $\mathrm{Cd}$ concentration at which levels in green fodder exceed the EC quality standards vary from 2.1 to $4.8 \mathrm{mg} \mathrm{kg}^{-1}$. This shows that the inclusion of SPT functions in the calculations of soil threshold concentrations allows one to account for the lower availability of $\mathrm{Cd}$ to plants at higher $\mathrm{pH}$ values. For $\mathrm{Cd}, \mathrm{Cu}$ and $\mathrm{Zn}$ both soil $\mathrm{pH}$ and $\operatorname{OrgC} \%$ affect the green fodder levels of the contaminants while for $\mathrm{Pb}$ it is important to consider $\mathrm{Al}_{\mathrm{ox}}$ when evaluating risks associated to the transfer of this element into the food chain.

With the exception of $\mathrm{Cu}$, soil threshold concentrations in view of animal health criteria exceed those based on food safety criteria. This means that thresholds based on the protection of human health implicitly also protect animal health. For $\mathrm{Cu}$, the limit concentration in cow kidney in view of animal health found in literature was more stringent than the limit concentration defined for food safety (Table 2) which explains why calculated Cu soil threshold concentrations in view of animal health ranged from 115 to $237 \mathrm{mg} \mathrm{kg}^{-1}$ d.w. but were $437-703 \mathrm{mg} \mathrm{kg}^{-1}$ d.w. regarding food safety.

Soil threshold concentrations for $\mathrm{Cd}, \mathrm{Pb}, \mathrm{Hg}, \mathrm{As}, \mathrm{Cu}$ and $\mathrm{Zn}$ are in line with those already in use in Portugal for agricultural soils amended with sewage sludge and are comparable to thresholds from other countries. This suggests that the approach applied here can form a conceptual basis for a strategy for risk assessment regarding the protection of grazing animals and human health. The main advantage of such approach is that it takes into account the availability of the contaminants in soils which increases the accuracy of the assessment of risks of contaminated soils to cattle and humans. This approach must be calibrated or validated on a regional basis using information from soil quality monitoring programs and must applied only within the boundaries of its calibration.

\section{Conclusions}

In the present study a chain model approach was tested to assess the transfer of PTEs from soils to feed and food crops and from crops to grazing livestock (cow and sheep) and finally for humans. Although some of the sites included in the study are heavily affected by industrial and mining activities they are nevertheless actually being used for arable crop production and/or cattle grazing. The results included in this study can be used as a rather robust way to identify those fields which in fact should not be used for raising cattle or for the production of food and fodder products. The model also allows one to identify the major sources of exposure for different PTEs. For animals, for example, the ingestion of grass was the most relevant pathway for the intake of $\mathrm{Cd}, \mathrm{Zn}, \mathrm{Cr}$, Se, Mo, B, Ni, Ba, $\mathrm{Cu}$ and $\mathrm{Hg}$ while for $\mathrm{Pb}, \mathrm{Co}, \mathrm{As}, \mathrm{U}$ and $\mathrm{Sb}$ the direct ingestion of soils accounts for around half of the element intake. The analysis of the pathways for human exposure of the toxic elements $\mathrm{Cd}, \mathrm{Pb}, \mathrm{Hg}$ and As showed that the removal of animal (cow) liver and kidney from the food chain is an option to substantially reduce human dietary intake for $\mathrm{Cd}$ and $\mathrm{Hg}$ at the industrial and Caveira mining area. For As and $\mathrm{Pb}$ the contribution of offal to human exposure is smaller compared to $\mathrm{Cd}$ and $\mathrm{Hg}$ and exposure due to intake of $\mathrm{As}$ and $\mathrm{Pb}$ from soil therefore remains relatively high at these areas.

This study showed that the $\mathrm{CaCl}_{2}$ extraction (a fast and simple soil analysis) can be used to determine whether or not a crop can be grown at a specific site by back-calculating soil threshold concentrations from EC feed/food crop quality standards which can be particularly useful at the local scale. Since soil quality monitoring programs often do not include data on the available pools of PTEs in soils, information on total element concentrations and key soil properties can be used as an alternative to derive regional soil threshold concentrations. This 
Table 6

Calculated soil threshold concentrations for PTEs and soil quality criteria available from Portugal and other countries.

\begin{tabular}{|c|c|c|c|c|c|c|c|c|c|c|c|c|c|c|}
\hline & \multicolumn{3}{|l|}{$\mathrm{Cd}$} & $\mathrm{Hg}$ & \multicolumn{3}{|l|}{$\mathrm{Pb}$} & As & \multicolumn{3}{|l|}{$\mathrm{Cu}$} & \multicolumn{3}{|l|}{$\mathrm{Zn}$} \\
\hline \multicolumn{15}{|c|}{ Soil threshold total concentrations ${ }^{\mathrm{a}}\left(\mathrm{mg} \mathrm{kg}^{-1}\right.$ d.w. $)$ - This study } \\
\hline & $\begin{array}{l}\mathrm{pH}=4 \\
\text { Org } \mathrm{C}=3 \%\end{array}$ & $\begin{array}{l}\mathrm{pH}=5 \\
\operatorname{Org} \mathrm{C}=3 \%\end{array}$ & $\begin{array}{l}\mathrm{pH}=6 ; \\
\operatorname{Org} \mathrm{C}=3 \%\end{array}$ & & $\begin{array}{l}\mathrm{Al}_{\mathrm{ox}}=50 \\
\mathrm{mmol} \mathrm{kg}\end{array}$ & $\begin{array}{l}\mathrm{Al}_{\mathrm{ox}}=100 \\
\mathrm{mmol} \mathrm{kg}\end{array}$ & $\begin{array}{l}\mathrm{Al}_{\mathrm{ox}}=150 \\
\mathrm{mmol} \mathrm{kg}\end{array}$ & & $\begin{array}{l}\mathrm{pH}=4 \\
\operatorname{Org} \mathrm{C}=3 \%\end{array}$ & $\begin{array}{l}\mathrm{pH}=5 \\
\operatorname{Org} \mathrm{C}=3 \%\end{array}$ & $\begin{array}{l}\mathrm{pH}=6 \\
\mathrm{Org} \mathrm{C}=3 \%\end{array}$ & $\begin{array}{l}\mathrm{pH}=4 \\
\operatorname{Org} \mathrm{C}=3 \%\end{array}$ & $\begin{array}{l}\mathrm{pH}=5 \\
\operatorname{Org} \mathrm{C}=3 \%\end{array}$ & $\begin{array}{l}\mathrm{pH}=6 ; \\
\text { Org } \mathrm{C}=3 \%\end{array}$ \\
\hline $\begin{array}{l}\text { Green fodder production (Lolium } \\
\text { perenne) }\end{array}$ & 2.1 & 3.1 & 4.8 & 1.9 & 411 & 618 & 789 & 85 & 87 & 168 & 324 & 367 & 592 & 955 \\
\hline Food safety (cow-kidney) & 0.5 & 0.7 & 1.0 & 0.7 & 51 & 70 & 82 & 775 & 3177 & 3536 & 3845 & o.c. & o.c. & o.c. \\
\hline Food safety (cow-liver) & 1.6 & 2.4 & 3.6 & 5.6 & 113 & 152 & 179 & 1483 & 437 & 570 & 703 & 1181 & o.c. & o.c. \\
\hline Animal health (cow-kidney) & 3.4 & 4.9 & 7.1 & 65 & 332 & 446 & 524 & 6561 & 115 & 171 & 237 & o.c. & o.c. & o.c. \\
\hline \multicolumn{15}{|c|}{ Soil threshold available concentrations ${ }^{\mathrm{b}}\left(m g \mathrm{~kg}^{-1} d . w.\right)-$ This study } \\
\hline $\begin{array}{l}\text { Green fodder production (Lolium } \\
\text { perenne) }\end{array}$ & 0.3 & & & 0.004 & 71 & & & 0.53 & 1.9 & & & 21 & & \\
\hline \multicolumn{15}{|c|}{ Soil quality criteria other countries (soil total concentrations, $m g \mathrm{~kg}^{-1}$ d.w.) (source: Carlon, 2007) } \\
\hline $\begin{array}{l}\text { Portugal (agricultural soils amended } \\
\text { with sewage sludge) }\end{array}$ & \multicolumn{3}{|c|}{$\begin{array}{l}1(\mathrm{pH}<5.5) 3(5.5<\mathrm{pH}<7.0) 4 \\
(\mathrm{pH}>7.0)\end{array}$} & $\begin{array}{l}1(\mathrm{pH}<5.5) 1.5 \\
(5.5<\mathrm{pH}<7.0) 2(\mathrm{pH}>7.0)\end{array}$ & \multicolumn{3}{|c|}{$\begin{array}{l}50(\mathrm{pH}<5.5) 300(5.5<\mathrm{pH}<7.0) 450 \\
(\mathrm{pH}>7.0)\end{array}$} & n.a. & \multicolumn{3}{|c|}{$\begin{array}{l}50(\mathrm{pH}<5.5) 100(5.5<\mathrm{pH}<7.0) 200 \\
(\mathrm{pH}>7.0)\end{array}$} & \multicolumn{3}{|c|}{$\begin{array}{l}150(\mathrm{pH}<5.5) 300(5.5<\mathrm{pH}<7.0) \\
450(\mathrm{pH}>7.0)\end{array}$} \\
\hline $\begin{array}{l}\text { UK (soil guideline values: allotments) } \\
\text { (based on a sandy loam soil with 6\% } \\
\text { organic matter concentration) }\end{array}$ & \multicolumn{3}{|c|}{1.8} & 80 (inorganic $\mathrm{Hg}$ ) & \multicolumn{3}{|c|}{ n.a. } & 43 & \multicolumn{3}{|c|}{ n.a. } & \multicolumn{3}{|c|}{ n.a. } \\
\hline $\begin{array}{l}\text { The Netherlands (maximum values for } \\
\text { residential land use) (standard soil } \\
10 \% \mathrm{OM} ; 25 \% \text { clay) }\end{array}$ & \multicolumn{3}{|l|}{1.2} & 10 & \multicolumn{3}{|l|}{70} & 97 & \multicolumn{3}{|l|}{790} & \multicolumn{3}{|l|}{1800} \\
\hline $\begin{array}{l}\text { Flanders, Belgium (clean-up values; } \\
\text { agricultural areas) }\end{array}$ & \multicolumn{3}{|l|}{2} & 10 & \multicolumn{3}{|l|}{200} & 45 & \multicolumn{3}{|l|}{200} & \multicolumn{3}{|l|}{600} \\
\hline
\end{tabular}

o.c. $=$ value not included because it was outside the SPT model calibration range. n.a. $=$ not available

a Soil total concentrations = aqua regia extraction for $\mathrm{Cd}, \mathrm{Pb}, \mathrm{As}, \mathrm{Cu}$ and $\mathrm{Zn}$; total concentrations for $\mathrm{Hg}$.

b Soil available concentrations $=0.01 \mathrm{M} \mathrm{CaCl}_{2}$ extraction.

c Decreto-Lei 276/2009, from 2nd October 2009. 
study showed that SPT models allow one to account for availability of contaminants in soils in the derivation of such thresholds. These models should be used within the bounds of their calibration, and should be calibrated or validated using local soil conditions on a regional basis. Soil threshold concentrations for $\mathrm{As}, \mathrm{Cd}, \mathrm{Cu}, \mathrm{Pb}, \mathrm{Hg}$ and $\mathrm{Zn}$ thus derived appear to be in line with those proposed in various EU countries.

\section{Acknowledgments}

S.M. Rodrigues acknowledges the financial support from the Portuguese Foundation for Science and Technology (FCT), under the Post-Doc grant SFRH/BPD/71072/2010.

This study was financed by FEDER funding through the "Programa Operacional Factores de Competitividade - COMPETE" and by Portuguese National funding through FCT - "Fundação para a Ciência e a Tecnologia" in the scope of Project "Ref ${ }^{\mathrm{a}}$ FCOMP-01-0124-FEDER014149 (FCT PTDC/AGR-PRO/114956/2009)”.

The support of Alterra - Wageningen UR (The Netherlands) in the development of this investigation is also acknowledged.

\section{References}

ACAF (Advisory Committee on Animal Feedingstuffs). Copper poisoning in sheep. Seventh ACAF Meeting 30 November 2000 - Information paper; 2000. ACAF/00/55.

Beresford NA, Crout NMJ, Mayes RW. The transfer of arsenic to sheep tissues. J Agr Sci 2001;136:331-44.

Brand E, Otte PF, Lijzen JPA. CSOIL 2000: an exposure model for human risk assessment of soil contamination. A model description. The Netherlands: RIVM Bilthoven; 2007. RIVM report 711701054

Brus DJ, de Gruijter JJ, Römkens PFAM. Probabilistic quality standards for heavy metals in soil derived from quality standards in crops. Geoderma 2005:128:301-11.

Derivation methods of soil screening values in Europe. In: Carlon C, editor. A review and evaluation of national procedures towards harmonization. Joint Research Centre: Ispra: European Commission; 2007. EUR 22805-EN.

Costley CT, Mossop KF, Dean JR, Garden LM, Marshall J, Carroll J. Determination of mercury in environmental and biological samples using pyrolysis atomic absorption spectrometry with gold amalgamation. Anal Chim Acta 2000;405:179-83.

Crews HM, Baxter MJ, Bigwood T, Burrell JA, Owen LM, Robinson C, et al. Lead in feed incident - multi-element analysis of cattle feed and tissues by inductively coupled plasma-mass spectrometry and co-operative quality assurance scheme for lead analysis of milk. Food Addit Contam 1992;9:365-78.

de Vries W, Römkens PFAM, Schütze G. Critical soil concentrations of cadmium, lead, and mercury in view of health effects on humans and animals. Rev Environ Contam T 2007;191:91-130.

EC (European Commission). Directive 2002/32/EC of the European Parliament and of the Council of 7 May 2002 on undesirable substances in animal feed; 2002.

EC (European Commission). Report from Task 3.2.11: assessment of the dietary exposure to arsenic, cadmium, lead and mercury of the population of the EU Member States. European Commission, Directorate-General Health and Consumer Protection; 2004. SCOOP report.

EC (European Commission). Communication from the Commission to the Council, the European Parliament, the European Economic and Social Committee and the Committee of the Regions. Thematic Strategy for Soil Protection, COM; 2006a. p. 231.

EC (European Commission). Commission Regulation (EC) No 1881/2006 of 19 December 2006 setting maximum levels for certain contaminants in foodstuffs; 2006b.

EC (European Commission). Commission Regulation (EC) No 479/2006 of 23 March 2006 as regards the authorisation of certain additives belonging to the group compounds of trace elements; 2006c.

Efroymson RA, Sample BE, Suter W. Uptake of inorganic chemicals from soil by plant levels: regressions of field data. Environ Toxicol Chem 2001;20:2561-71.

Franz E, Römkens P, van Raamsdonk L, van der Fels-Klerx I. Chain modeling approach to estimate the impact of soil cadmium pollution on human dietary exposure. J Food Protect 2008;71(12):2504-13.
Gál J. Hursthouse A, Tatner P. Stewart F, Welton R. Cobalt and secondary poisoning in the terrestrial food chain: data review and research gaps to support risk assessment. Environ Int 2008;34:821-38

Houba VJG, Temminghoff EJM, Gaikhorst GA, Van Vark W. Soil analysis procedures using $0.01 \mathrm{M}$ calcium chloride as extraction reagent. Commun. Soil Sci. Plan 2000;31:1299-396

Inacio $\mathrm{M}$, Pereira V, Pinto $\mathrm{M}$. The soil geochemical atlas of Portugal: overview and applications. J Geochem Explor 2008;98:22-33.

INE (Instituto Nacional de Estatística). Balança Alimentar Portuguesa 1990-2003. Portugal: Lisboa; 2006.

Kabata-Pendias A. Trace elements in soils and plants. third ed. Boca Raton: CRC Press LLC; 2001.

Kalis EJJ, Temminghoff EJM, Visser A, Van Riemsdijk WH. Metal uptake by Lolium perenne in contaminated soils using a four-step approach. Environ Toxicol Chem 2007;26:335-45.

Krauss M, Wolfgang W, Kobza J, Zech W. Predicting heavy metal transfer from soil to plant: potential use of Freundlich-type functions. J Plant Nutr Soil Sc 2002;165: 3-8.

López Alonso M, Benedito JL, Miranda M, Castillo C, Hernández J, Shore RF. Arsenic, cadmium, lead, copper and zinc in cattle from Galicia NW Spain. Sci Total Environ 2000;246:237-48.

Miranda M, Benedito JL, Blanco-Penedo I, López-Lamas C, Merino A, López-Alonso M. Metal accumulation in cattle raised in a serpentine-soil area: relationship between metal concentrations in soil, forage and animal tissues. J Trace Elem Med Bio 2009;23:231-8

Nriagu J, Boughanen M, Linder A, Howe A, Grant C, Rattray R, et al. Levels of As, Cd, Pb, $\mathrm{Cu}$, Se and $\mathrm{Zn}$ in bovine kidneys and livers in Jamaica. Ecotoxicol Environ Saf 2009;72:564-71.

O'Connor GA, Brobst RB, Chaney RL, Kincaid RL, McDowell LR, Pierzynski GM, et al. A modified risk assessment to establish molybdenum standards for land application of biosolids. J Environ Qual 2001;30:1490-507.

Prankel SH, Nixon RM, Phillips CJ. Implications for the human food chain of models of cadmium accumulation in sheep. Environ Res 2005;97:348-58.

Reis AT, Rodrigues SM, Araújo C, Coelho JP, Pereira E, Duarte AC. Mercury contamination in the vicinity of a chlor-alkali plant and potential impacts on local population. Sci Total Environ 2009;407(8):2689-700.

Rodrigues SM, Pereira ME, Ferreira da Silva E, Hursthouse A, Duarte AC. A review of regulatory decisions for environmental management: part II-the case-study of contaminated land management in Portugal. Environ Int 2009;35:214-25.

Rodrigues SM, Henriques B, Ferreira da Silva E, Pereira ME, Duarte AC, Römkens PFAM. Evaluation of an approach for the characterization of reactive and available pools of twenty potentially toxic elements in soils: part I - the role of key soil properties in the variation of contaminants' reactivity. Chemosphere 2010a;81:1549-59.

Rodrigues SM, Henriques B, Ferreira da Silva E, Pereira E, Duarte AC, Groenenberg JE, et al. Evaluation of an approach for the characterization of reactive and available pools of twenty potentially toxic elements in soils: part II - solid-solution partition relationships and ion activity in soil solutions. Chemosphere 2010b:81:1560-70.

Römkens PFAM, Guo HY, Chu CL, Liu TS, Chiang CF, Koopmans GF. Characterization of soil metal pools in paddy fields in Taiwan: chemical extraction and solid-solution partitioning. J. Soil Sediment 2009a;9(3):216-28.

Römkens PF, Guo HY, Chu CL, Liu TS, Chiang CF, Koopmans GF. Prediction of cadmium uptake by brown rice and derivation of soil-plant transfer models to improve soil protection guidelines. Environ Pollut 2009b;157(8-9):2435-44.

Sedki A, Lekouch N, Gamon S, Pineau A. Toxic and essential trace metals in muscle, liver and kidney of bovines from a polluted area of Morocco. Sci Total Environ 2003;317 (1-3):201-5.

Smith KM, Abrahams PW, Dagleish MP, Steigmajer J. The intake of lead and associated metals by sheep grazing mining-contaminated floodplain pastures in mid-Wales, UK: I. Soil ingestion, soil-metal partitioning and potential availability to pasture herbage and livestock. Sci Total Environ 2009;407:3731-9.

Swartjes FA, editor. Dealing with contaminated sites - from theory towards practical application. The Netherlands: Springer; 2011

Válega M, Lillebø AI, Pereira ME, Caçador I, Duarte AC, Pardal MA. Mercury in salt marshes ecosystems: Halimione portulacoides as biomonitor. Chemosphere 2008;73:1224-9.

Van Hooft WF. Risico's voor de volksgezondheid als gevolg van blootstelling van runderen aan sporenelementen bij beweiding. Rapport 693810 001Rijksinstituut voor Volksgezondheid en Milieuhygiëne. Nederland: Bilthoven; 1995. 